\title{
COMPARISON BETWEEN PUBLIC AND PRIVATE PAY STRUCTURES IN BANGLADESH
}

\author{
N Sultana ${ }^{1}$ and P C Modak ${ }^{2}$
}

\begin{abstract}
A survey was carried out during the period from July to December 2002 to see comparison between public and private pay structures in Bangladesh. To evaluate the public pay structure 120 respondents of Bangladesh Agricultural University (BAU) were interviewed through semistructured questionnaire. The respondents were categorized in 8 different categories. Information of their monthly salary, income tax etc. were checked against their pay-bills and income tax information as supplier by the employer. The secondary data on also collected personally by researcher himselves Pay-structure of different organizations, National pay scales and Price indices. It was found that almost all employees including teachers and officers are facing constraints to maintain their families with income from their job. About $65.5 \%$ of their expenditure is getting from their salaries. More than 36\% of the employees (including teachers and officers) failed to manage their family expenditure with income from job and extra job. National Pay scale 1997 reduced sufficiently the disparity between the highest and the lowest salary to 10:1 whereas in 1991 the ratio was 11.11:1. In private sectors like Pubali Bank Limited (PBL), Islami Bank Bangladesh Limited (IBL) and Uttara Bank Limited (UBL) the disparity between the highest and the lowest salary were found 21.1:1, 25.29:1 and 26:1 respectively. But disparity in NPS does not ensure the equity, fairness and justice to the civil servants or employees because salaries were not sufficient to cover the cost of as well as livelihood. The maximum salary one can draw is TK.23800 when a person is in the highest grade according to NPS 1997. On the other hand, in private organizations one can draw the highest amount of TK. 90500 which is more than 3.80 times of the highest amount drawn as per NPS 1997. House rent of private sectors varies from $65.4 \%$ to $104 \%$ (including house maintenance) where as in public sectors it varies from $40 \%$ to $55 \%$ of basic salary. Consequently, the living conditions of the service holders of lower income groups have been drastically reducing. The minimum salary ratio is to be suggested between the highest and the lowest position should be 5:1.
\end{abstract}

Key Words: Comparison, Public and Private Pay structure, Bangladesh

\section{INTRODUCTION}

The pay structure for the public services that Bangladesh inherited at independence was really peculiar in many respects. One of the anachronistic features of the erstwhile pay structure was multiplicity of scales. There were about 20 different grades of pay scales in the public sector. The primary causes of proliferation of the number of pay scales was the absence of a sound pay plan and their non-conformity to an overall pay policy and pay structure is out of tune of Bangladesh, particularly in the context of the social and economic goals set by the country its liberation (Obaidulla,1995). In Bangladesh the compulsory minimum salary has been accepted as a matter of social policy long time ago. It should be borne in mind that financial position of the government is completely irrelevant in determining the minimum salary of government servant. The factors that need examination for determination of minimum wages are: i) the size of the average family ii) basic needs of such average family iii) their prices. The minimum wage paid to an employee should be such as would enable him and his family to maintain a

\footnotetext{
${ }^{1}$ Student, Department of Agricultural Statistics, Bangladesh Agricultural University, Mymensingh

${ }^{2}$ Professor, Department of Agricultural Statistics, Bangladesh Agricultural University, Mymensingh
} 
minimum standard of living. But there is no standard which can be termed as minimum. In the context of 1976 when the Report of the pay and service commission was under preparation the cost of balanced diet for adult person was considered to be taka 67.37 per month (to this may be added taka 13.47 to cover the cost of fuel, clothing and other essential items (Obaidullah, 1995). It is the obligation of the Government to ensure economy and social security to all its citizens of any profession and occupation. The Constitution of People Republic of Bangladesh (1972) reflects that a fundamental responsibility of the state is to attain economic growth, to improved the material and cultural standard of living of the people with a view to secure the basic necessities of life including food, clothing, shelter, education and medical care and to guarantee the employed person at a reasonable wage having regard to the quality of work.

The main objective of this paper is to identify the inequalities between income and consumption of different categories of employees of NPS \& other pay-structures of different organizations, to compare among National Pay Scales (NPS) of different years-1991 and 1997 and to observe whether the Government of the people's republic of Bangladesh the guarantee to provide a reasonable salary/wage to the employed persons according to quality of work.

\section{MATERIALS AND METHODS}

The sample size of the present study was taken for 120 respondents in 8(eight) different categories viz Professor, Associate Professor, Assistant Professor, Lecturer, Section Officer (SO), Clerical Post (CP), Member of Lower Support Service (MLSS) and Daily labour of Bangladesh Agricultural University Mymensingh. From each of the categories 15 (fifteen) persons were selected on the basis of random sampling. While selecting the sample the easy availability of data was the main consideration. The study period from July to December 2002. The requisite primary data were collected on the basis of a structured questionnaire prepared in the light of the objectives of the study. The questionnaire was filled up by the respondents themselves of the upper 6 categories and the questionnaire for the lower 2 categories were filled up on the basis of their response. Since the study was related to 8 categories, information of their monthly salary, income tax etc. were checked against their pay-bills and income tax information as supplier by the employer. The secondary data which was collected includes: Pay -Structures of different organizations (Uttara Bank Ltd, Islami Bank Ltd, Pubali Bank Ltd and RDRS) along with National Pay Scales (NPS) of the years 1991 \& 1997 and Price indices.

\section{RESULTS AND DISCUSSIONS}

Findings of the study are presented in this chapter:

\section{i) Income -consumption ratio}

A formula for income consumption ratio (ICR) was developed to identify whether a person, either a service holder or otherwise, is economically viable. When ICR value is one, the person and his family is in critical point; below one means he is incapable to maintain his family expense with his present income; above one signifies he can manage his family expenditure with a particular income at a particular market price.To see the income-cost ratio, value of ICR was calculated as indicated in Table1. Using the formula

$\mathrm{V}=\mathrm{W}(100-\mathrm{t}) / 100] / \mathrm{C}$

Where

$$
\begin{aligned}
\mathrm{V} & =\text { value of ICR } \\
\mathrm{W} & =\text { Salary/Income (including tax) } \\
\mathrm{t} & =\text { tax rate } \\
\mathrm{C} & =\text { Cost of Living }
\end{aligned}
$$


It was found that about $37 \%$ of the respondents whose ICR values are lower than 1 were not able to maintain their families with the income (salary) as paid by their employer according to NPS 1997. More than $8 \%$ of the respondents whose ICR-values were $1<\mathrm{V}<1.05$ somehow maintain their family expense. About $80 \%$ of the MLSS were not abled to maintain their monthly family expenditure. It was observed that in all categories of respondents, there were a number of cases where ICR- values were lowered than one i.e. in all strata of the employee economically unhealthy nature were detected.

\section{ii) Increase in the cost of living between 1972-73 and 2002-2003}

A tremendous inflation in the money of Bangladesh was the reality after its liberation in 1971. As a result, cost of living of the people has also increase manifold. An estimate of the cost of living indices of the country is presented in Table 2. The figures relate to Government employees who are in the middle income group.

Table2. Annual average consumer price indices of Govt. employee (middle income group in Dhaka Base (1972-73=100)

\begin{tabular}{|l|l|l|l|}
\hline Year & General Index & Year & General Index \\
\hline $1972-73$ & 100 & $1988-89$ & 753 \\
\hline $1973-74$ & 138 & $1989-90$ & 823 \\
\hline $1974-75$ & 224 & $1990-91$ & 875 \\
\hline $1975-76$ & 209 & $1991-92$ & 918 \\
\hline $1976-77$ & 210 & $1992-93$ & 959 \\
\hline $1977-78$ & 303 & $1993-94$ & 988 \\
\hline $1978-79$ & 267 & $1994-95$ & 1087 \\
\hline $1979-80$ & 308 & $1995-96$ & 1079 \\
\hline $1980-81$ & 345 & $1996-97$ & 1125 \\
\hline $1981-82$ & 390 & $1997-98$ & 1193 \\
\hline $1982-83$ & 416 & $1998-99$ & 1263 \\
\hline $1983-84$ & 458 & $1999-00$ & 1346 \\
\hline $1984-85$ & 512 & $2000-01$ & 1295 \\
\hline $1985-86$ & 557 & $2001-02$ & 1340 \\
\hline $1986-87$ & 612 & $2002-03$ & 1419 \\
\hline $1987-88$ & 682 & & \\
\hline
\end{tabular}

Sources: modified and estimated from BBS 1992, 2000.

The analysis of cost of living indices of the different years reveals that the consumer prices have increased more than 14 times in 2002-2003 compared to price level of 1972-73. By 20022003, the consumer price-index has gone up to 1419 having 1972-73 as base i.e. at the middle of 2002-2003, Taka 1057 become worth TK. 15000 of 1972-73 in terms of real purchasing power.

\section{iii) Inequality in income and expenditure}

Inequality in incomes, expenditure and services of all categories of employees of BAU is shown in Table 3. Out of these 3 major items, highest inequality (0.68) was found in income, followed by services (1.25) and expenditure (3.64). The sources of income in the study were confined to job and extra jobs. In both sources inequalities ( 0.37 and 0.31 respectively) are less than the inequality in income. This implies that sources were unequal and it is not wise to combine them for comparison. On the other hand inequality of expenditure lies between the inequalities of food (2.46) includes rice $(-0.10)$ wheat $(0.10)$ pulses $(0.16)$ fish $(0.33)$ milk $(0.26)$ meat $(0.13)$ chicken $(0.34)$ egg $(0.18)$ cooking oil $(0.21)$ vegetables $(0.25)$ fruits $(0.33)$ tea/coffee $(-0.04)$ and confectionary product $(0.31)$ and non-food (1.18) includes clothing $(0.41)$ 
housing (0.47) and cosmetic (0.30). This implies, these two items (food \& non-food) are combinable for better comparison though highest inequalities (0.47) was found in housing followed by clothing (0.41).Inequality in education (0.36) was higher than medicine (0.25). This means educational expense increases in the families with higher income groups. The same picture was found in gas/fuel (0.23) and transport (0.23).

Table 3. Gini Lorenz ratio of Income, Expenditure and Services of employees at BAU

\begin{tabular}{|c|c|c|c|c|c|}
\hline \multicolumn{3}{|l|}{ Items } & \multicolumn{3}{|c|}{ Gini ratio } \\
\hline \multirow[t]{3}{*}{ A) Income } & & & 0.68 & & \\
\hline & i) Job & & & 0.37 & \\
\hline & ii) Extra job & & & 0.31 & \\
\hline \multirow[t]{6}{*}{ B)Expenditure } & & & 3.64 & & \\
\hline & i) Food & & & 2.46 & \\
\hline & ii) Non-food & & & 1.18 & \\
\hline & & Clothing & & & 0.41 \\
\hline & & Housing & & & 0.47 \\
\hline & & Cosmetic & & & 0.30 \\
\hline \multirow[t]{5}{*}{ C) Services } & & & 1.25 & & \\
\hline & i) Education & & & 0.36 & \\
\hline & ii) Medicine & & & 0.25 & \\
\hline & iii) Gas/Fuel & & & 0.32 & \\
\hline & iv)Transport & & & 0.32 & \\
\hline
\end{tabular}

\section{iv) Comparison of income, expenditure and family size of the respondents}

From the Table 4 it was observed that the ratio of working money on the hand of the highest and the lowest categories of employees (prof vs mlss) was found 3.64. This is the lowest disparity in income of the highest and the lowest grade. But the ratio of expenditure was 2.83 i.e. the extreme categories are closer in expenditure.

Table 4. Monthly income from jobs, expenditure and family size of different categories of employees of BAU

\begin{tabular}{|l|l|l|l|l|l|}
\hline $\begin{array}{l}\text { SL } \\
\text { NO }\end{array}$ & Designation & $\begin{array}{l}\text { Income from } \\
\text { job(TK) }\end{array}$ & $\begin{array}{l}\text { Total } \\
\text { Expenditure } \\
\text { (TK) }\end{array}$ & $\begin{array}{l}\text { Family } \\
\text { size (NO) }\end{array}$ & $\begin{array}{l}\text { ExpenditureIn } \\
\text { come ratio }\end{array}$ \\
\hline 1 & Daily Labours & 1360.00 & 3188.53 & 5.4 & 2.34 \\
\hline 2 & MLSS & 4340.00 & 6078.87 & 5.8 & 1.40 \\
\hline 3 & Clerical Post & 5065.72 & 7736.40 & 5.53 & 1.53 \\
\hline 4 & Section Officer & 9728.40 & 11828.03 & 5.67 & 1.23 \\
\hline 5 & Lecturer & 7775.13 & 9688.93 & $4.47 *$ & 1.25 \\
\hline 6 & Assistant Professor & 11927.53 & 11741.73 & 3.2 & 1.00 \\
\hline 7 & Associate Professor & 14553.33 & 18778.55 & 4.4 & 1.29 \\
\hline 8 & Professor & 15778.80 & 17217.76 & 4.5 & 1.09 \\
\hline
\end{tabular}

*They are bearing whole family expenses because mother, father, brother and sister depends on his/her income. So her/his family size is large.

Almost all employees including teacher and officers of the university cannot maintain their families with the cash they received as salary. The last columns of Table 4 indicates that income from job is not sufficient for their family expenditure. The most vulnerable groups are MLSS and Clerical Post. The corresponding expenditure were 1.4 and 1.53 times their income 
from job. Only assistant professor's job income and expenditure are equal. Their ratio is 1. Next to these are the professors whose ratio is 1.09. Data presented in Table 4 reveals that the family size was larger in lower grade (5.8) than the highest grade (4.5). It was found that assistant professor has the minimum family size (3.2). A thing is clear from the table that though assistant professors were able to manage their family expenditure with the job income may be due to their little family size.

\section{V) Comparison of main features in pay-structures of different organization}

Data presented in Table 5 reveal that the highest basic salaries were Taka 15000, 42200, 39200, 52000 and 39200 and the lowest were Taka 1500, 2000, 1550, 2000, 1600 in Go, UBL, IBL, PBL and RDRS respectively. The ratio of the highest and the lowest grades is the least (10:1) in Government organization, while in UBL the ratio is (26:1). House rent in government organization varies from $40 \%$ to $55 \%$ of the basic salary where as in PBL and IBL it is $65.5 \%$ to $102.4 \%$ and $76.5 \%$ to $90 \%$ (including house maintenance) for the top 9 grades and $70 \%$ for other grades, in UBL it is more than $104 \%$ (including house maintenance and utility) to $68 \%$ and in RDRS it is $70 \%$ of the basic salary.

In Government sectors one can draw a maximum amount of taka 23800 (including festival allowance) when he reaches to the highest scale. But in PBL, IBL, UBL and RDRS these mount are Taka 70950, 78040, 90500 and 67140 respectively, which are 2.98, 3.28, 3.80 and 2.82 times the higher than in governments sector.

Medical allowance in government sector is Taka 300 for all but in private sectors it varies widely. In PBL, IBL and UBL medical allowances were Taka 250 to 1000, 380 to 4900 and 1000 to 3000 from the lowest to the highest grade. In RDRS the allowance was TK.500 for all categories of employees.

No conveyance allowance is given in Government organizations except $3^{\text {rd }}$ and 4rd class employees who are paid monthly Tk.80. Of course transport facilities are provided to administrative officers. On the other hand PBL, IBL and UBL provided monthly Tk. 200 to 250, 500 to 1200 and 500 to 3500 to the employees of different grades. Officers of higher grades can use cars in IBL and UBL. The information regarding transport facilities in PBL and RDRS were not available. 
Table 5: A comparison of main features in Pay-structures of different organizations (Public \& Private)

\begin{tabular}{|c|c|c|c|c|c|c|c|c|c|c|c|c|}
\hline \multirow[t]{2}{*}{ Organization } & \multirow{2}{*}{$\begin{array}{l}\text { Pay-structure } \\
\text { approved in the } \\
\text { year }\end{array}$} & \multirow{2}{*}{$\begin{array}{l}\text { No of } \\
\text { structure }\end{array}$} & \multirow{2}{*}{$\begin{array}{l}\text { Lowest } \\
\text { salary } \\
\text { (basic) } \\
\text { in TK. }\end{array}$} & \multirow{2}{*}{$\begin{array}{l}\text { Highest } \\
\text { salary } \\
\text { (basic) in } \\
\text { TK. }\end{array}$} & \multirow{2}{*}{$\begin{array}{l}\text { Ratio of } \\
\text { highest to } \\
\text { lowest }\end{array}$} & \multicolumn{7}{|c|}{ Other allowances ( TK / Month or other facilities) } \\
\hline & & & & & & $\begin{array}{l}\text { House } \\
\text { Rent (TK/Month ) }\end{array}$ & $\begin{array}{l}\text { Medical } \\
\text { allowance } \\
\text { (TK/Month) }\end{array}$ & $\begin{array}{l}\text { House } \\
\text { maintenance } \\
\text { (TK/Month) }\end{array}$ & $\begin{array}{l}\text { Conveyance } \\
\text { (TK/Month) }\end{array}$ & $\begin{array}{l}\text { Utilities } \\
\text { (TK/Month) }\end{array}$ & $\begin{array}{l}\text { Entertainment } \\
\text { (per month) }\end{array}$ & $\begin{array}{l}\text { Festival } \\
\text { allowance } \\
\text { / } \\
\text { Washing } \\
\text { (per year) }\end{array}$ \\
\hline National & 1997 & 20 & 1500 & 15000 & 10 & 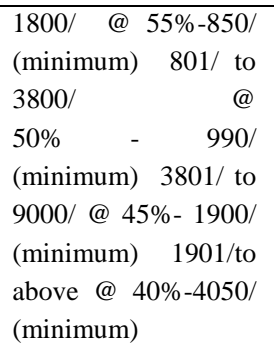 & $300 /$ & Nil & $\begin{array}{l}80 \% \quad \text { for } \\
\text { class iii \& iv } \\
\text { employees }\end{array}$ & Nil & $100 /$ & $\begin{array}{l}2 \text { month } \\
\text { basic pay }\end{array}$ \\
\hline $\begin{array}{l}\text { Pubali } \quad \text { Bank } \\
\text { Limited }\end{array}$ & 2000 & 13 & 2000 & 42200 & 21.1 & $50 \% \quad 60 \%$ & $250 / 1000 /$ & $\begin{array}{l}750 / \\
6500 /\end{array}$ & $\begin{array}{l}200 / \\
250 /\end{array}$ & & & \\
\hline $\begin{array}{l}\text { Islamic Bank } \\
\text { Bangladesh } \\
\text { Limited }\end{array}$ & 2000 & 20 & 1550 & 39200 & 25.29 & $40 \%-70 \%$ & $380 /-4900 /$ & $30 \%-20 \%$ & $500 /-1200 /$ & $6500 /-5000 /$ & & \\
\hline $\begin{array}{ll}\text { Uttara } & \text { Bank } \\
\text { Limited } & \end{array}$ & 2002 & 12 & 2000 & 52000 & 26.0 & $\begin{array}{l}68 \% \text { of basic to } \\
25000 /\end{array}$ & $1000 /-3000 /$ & $2000 /-5000 /$ & 500/-3500/; & $3000 /-2000 /$ & $2500 /$ & $200 /$ \\
\hline $\begin{array}{l}\text { Rangpur } \\
\text { Dinajpur Rural } \\
\text { Service }\end{array}$ & 2001 & 8 & 1600 & 39200 & 24.5 & $70 \%$ & $500 /$ & & & & & \\
\hline
\end{tabular}




\section{vi Change of the National pay-scales over NPS 1977}

Table 6 reveals the percent change of the National pay-scales in 1991 and 1997 over the National pay-scales in 1977. Each scale is devised into 3 sections starting values, mid values and last values of the scale. It was observed that in a particularly pay-structure the nature of change in all 3 sections are more or less similar. In 1977, in 1991 it was 3 to 4.2 times and 4.5 to 6.5 times in 1997. In 1991 mid-value increases 3.18 to 4.84 times and in 1997 it was 4.77 to 7.4 times over of the mid-value in NPS 1977. Last values of the scale increase 3.26 to 5.29 times in 1991 and in 1997 it was 4.85 to 8.02 times.

Table 6 Percent change of the national pay-scales over NPS 1977

\begin{tabular}{|l|l|l|}
\hline \multirow{2}{*}{ Value of scale } & \multicolumn{2}{|l|}{ National pay-scales of the year } \\
\cline { 2 - 3 } & 1991 & 1997 \\
\hline Starting-value(\%) & $302-420$ & $453-650$ \\
\hline Last -value(\%) & $326-529$ & $485-802$ \\
\hline
\end{tabular}

\section{vii) Change of pay-structures of private organization over NPS 1997}

From Table 7 it was observed that in al the private organizations starting value, mid value and last value of pay scale were higher than the corresponding values in NPS 1997. The starting value was the highest in IBL which ranges from 1.58 to 1.76 times than NPS 1997 followed by UBL where it was 1.17 to 1.67 times. The starting value of top grade in RDRS was 1.6 times than NPS 1997, but other grades of RDRS were lower. The mid-values were the highest in UBL which ranges from 1.33 to 2.57 times than NPS 1997 followed by IBL where it was 1.61 to 2.19 times. Last value of scale was the highest in UBL which extended up to 3.47 times the corresponding values in NPS 1997. In both IBL and RDRS it was 2.61 times and in PBL, the value was 2.81 times over NPS 1997.

Table 7 Percent change of pay-structures of private Banks over NPS 1997

\begin{tabular}{|l|l|l|l|l|}
\hline Qrganization (Year) & PBL(2000) & IBL(2000) & UBL(2002) & RDRS(2001) \\
\hline Scale & & & & \\
\hline Starting value(\%) & $123-135$ & $158-176$ & $117-167$ & $96-160$ \\
\hline Last value(\%) & $118-281$ & $164-261$ & $126-347$ & $121-261$ \\
\hline
\end{tabular}

\section{DISCUSSION}

It was observed that each of the two National Pay Scale 1991 (11.11:1) and 1997 (10:1) failed to set a pay structure which was getting the cost of living as well as livelihood of the employees. Fourth Revised National Pay Scale was announced in 1991 with a differential of 11.11:1 between the highest and the lowest salary which in fact failed to achieve the goal. The government announced the Fifth New Pay Scale in 1997. The scale containing 20 grades with a differential of 10 between the highest and the lowest salary. On the other hand, pay-structures of Pubali Bank Limited (PBL) and Islami Bank Bangladesh (IBL) were in operation since 2000 having differentials 21.1:1 and 25.29:1 between the highest and the lowest salary respectively. But this is a great concerned situation as the salaries according NPS 1997 which is not sufficient to maintain 
the family expenditure. From a survey of all categories of employees including teachers of Bangladesh Agricultural University it was found that almost all the respondents were facing problem to maintain their families with their salaries. In Govt. organizations low job satisfaction is a regular practice. Low status and low working conditions are the main factors for bad performance in govt-sector. This has reduced the government's strength in recruiting the best and efficiency manpower. In private sectors the degree of skill and intelligence was considered but a little attention was given to minimize the differential of salary between the highest and the lowest grades. The bureaucratic system allows the civil servants to acquire huge wealth through corruption.

\section{CONCLUSION}

The Government of Bangladesh fixed pay structure at an artificially lower level based on nutritional uptake and other expenditures which are not directly relevant to practical life. This need not imply that many families cannot maintain their expenditure with their poor salaries. Because the market price of all commodities are ever changing at higher rates but the income of employees are not changing too frequently. However, for a happy blending of the employees to rationalize the pay structure: The minimum salary should be fixed in such premise that would at least fulfils the basic needs of the respective family. The salary ratio between the highest and the lowest position should be 5 . The discrepancy between the private and public pay-scales should not exceed $10 \%$ to preserve a semblance of social justice.

\section{REFERENCES}

HUQ, B. I. A..(2000). "Economic and Social Security in Bangladesh: A comparative Analysis of Some Selected Persons of Different Professions.” Social Science Review, Vol. 17, No.2, December, pp.296

Maheshvarananda, Avt. Acarya. (2002). "The crisis of Global capitalism and Economic Depression”. PROUT, August 16-31 pp.50.

NPC. (1973). Cited in A.T.M. Obuidullah. (1992). "Administrative Reforms in Bangladesh Implementation Strategy”. Unpublished Ph. D Dissertation. Department of Political Science. University of Rajshahi.

Obaidullah, A. T. M. (1995). "Reorganization by Pay-policy and Structure in Bangladesh:Quest for Living Wage”. Journal of Asiatic Society of Bangladesh. Vol. 40, No.1, June, pp.135156.

P \& SC, Government of Bangladesh.(1977).

Siddique,1 A.H.(1989), "Need satisfaction of the Executives in Industry and Government in Bangladesh”. The Dhaka University Studies. Part C, Vol. 10(1),pp.179-188.

Siddique,2 A.H.(1989). Maintenance of the Salary Structure in Relation to Cost of Living: An Analysis for the Executives in the Public Sector Enterprises In Bangladesh”. The Dhaka University Studies. Part C, Vol. 10(2), pp.115-121.

The constitution of the people's Republic of Bangladesh. (1994). Article No.19(2). 